\title{
PENETRATION, DEVELOPMENT, AND REPRODUCTION OF Meloidogyne enterolobii ON Psidium SPECIES AND INDUCED CELLULAR RESPONSES IN THE ROOTS ${ }^{1}$
}

\author{
ALAIN DENIS DE SOUSA ${ }^{2}$, ELVIRA MARIA RÉGIS PEDROSA ${ }^{3}$, CLÁUDIA ULISSES ${ }^{4}$, \\ JOSÉ MAURO DA CUNHA E CASTRO ${ }^{5}$, JULIANA MARTINS RIBEIRO ${ }^{6}$
}

ABSTRACT Meloidogyne enterolobii has severely compromised the main guava producing regions in Brazil, thereby stimulating the development of resistant varieties for efficient management of this nematode. This study aimed to assess the penetration, development, reproduction, and induced cellular responses of $M$. enterolobii in roots of four species of the genus Psidium (P. guajava 'Paluma', P. guineense, P. cattleyanum, and $P$. friedrichstalianum) from the Active Germplasm Bank (BAG) of the Center for Agricultural Research of the Semi-arid Tropics (Embrapa Semi-arid) located in Petrolina, PE, Brazil. Three experiments were carried out to assess the penetration, development, and reproduction of the nematode and, subsequently, histological analyses were performed. Nematode penetrated indistinctly in both resistant and susceptible species, but only in 'Paluma' an evolution was observed from vermiform juveniles to "sausage" and globose forms in experiment 1 . In experiment 2 , all species presented "sausage" forms of nematode, but only in 'Paluma', these forms reached adult female stages. In experiment 3, only 'Paluma' was susceptible to M. enterolobii, with reproduction factor above unity. Histological analyses showed that, except for P. guajava, the other Psidium species presented poorly developed feeding sites at 20 days after inoculation.

Index Terms: Guava root-knot nematode, Psidium cattleyanum, P. friedrichstalianum, P. guajava, $P$. guineense, resistance.

\section{PENETRAÇÃO, DESENVOLVIMENTO E REPRODUÇÃO DE Meloidogyne enterolobii EM ESPÉCIES DE Psidium E RESPOSTAS CELULARES INDUZIDAS NAS RAÍZES}

RESUMO A presença de Meloidogyne enterolobii nas principais regiões de cultivo de goiabeira tem comprometido severamente a produção brasileira do fruto e estimulado o desenvolvimento de variedades resistentes para manejo eficiente do nematoide. O presente estudo teve como objetivos avaliar a penetração, o desenvolvimento, a reprodução e as respostas celulares induzidas por M. enterolobii nas raízes de quatro espécies do gênero Psidium ( $P$. guajava 'Paluma', P. guineense, $P$. cattleyanum e $P$. friedrichstalianum), provenientes do Banco Ativo de Germoplasma (BAG) do Centro de Pesquisa Agropecuária do Trópico Semiárido (Embrapa Semiárido), localizado em Petrolina-PE. Foram realizados três experimentos para a avaliação da penetração, desenvolvimento e reprodução do nematoide, e, ao final, realizadas análises histológicas. O nematoide penetrou indistintamente nas espécies resistentes e suscetíveis, mas apenas em 'Paluma' houve evolução dos juvenis vermiformes para as formas salsichoides e globosas, no experimento 1. No experimento 2, em todas as espécies, havia formas salsichoides do nematoide, porém, apenas em 'Paluma', elas chegaram a fêmeas adultas. No experimento 3, apenas 'Paluma' mostrou-se suscetível a $M$. enterolobii com fator de reprodução maior do que 1. As análises histológicas mostraram que, ao contrário de P. guajava, as demais espécies de Psidium apresentaram sítios de alimentação pouco desenvolvidos aos 20 dias após a inoculação.

Termos para indexação: Nematoide-das-galhas da goiabeira, Psidium cattleyanum, P. friedrichstalianum, P. guajava, P. guineense, resistência.

\footnotetext{
'(Paper 230-15). Received September, 29 2015. Accepted February 17, 2016.

${ }^{2}$ Master in Plant Pathology. Graduate student, Universidade Federal Rural de Pernambuco (UFRPE), Recife-PE, Brazil. E-mail: alaindenisssousa@gmail.com

${ }^{3} \mathrm{PhD}$ in Plant Pathology, Professor, Universidade Federal Rural de Pernambuco (UFRPE), Recife-PE, Brazil. E-mail: elvira.pedrosa@ ufrpe.br. *Corresponding author.

${ }^{4}$ Dra in Botany. Professor, Universidade Federal Rural de Pernambuco (UFRPE), Recife-PE, Brazil. E-mail: claulisses@gmail.com ${ }^{5}$ Dr in Plant pathology. Researcher, Empresa Brasileira de Pesquisa Agropecuária (Embrapa), Petrolina-PE, Brazil. E-mail: mauro. castro@embrapa.br

${ }^{6}$ Dra in Crop Production. Researcher, Empresa Brasileira de Pesquisa Agropecuária (Embrapa), Petrolina-PE, Brazil. E-mail: juliana. ribeiro@embrapa.br
} 


\section{INTRODUCTION}

The genus Psidium belongs to the family Myrtaceae, which comprises about 140 genera and 3,000 species (GOMES et al., 2009), most of which cultivated in regions of tropical and subtropical climate for commercial purposes. About 150 species are included in this genus, especially Psidium guajava L., P. cattleyanum Sabine, and $P$. guineense Swartz (PEREIRA and NACHTIGAL, 2003).

Although guava ( $P$. guajava) is the most economically important species, several other Psidium species produce edible fruits and timber or are ornamental, presenting the potential for commercial exploitation (BEZERRA et al., 2006). Among these species, stand out $P$. cattleyanum and $P$. guineense, due to the fruit characteristics with exotic flavor, high vitamin $\mathrm{C}$ content, and a good consumer acceptance (MANICA et al., 2000).

Brazil is one of the world's largest producers of guava and its cultivation is distributed throughout the country (ROZANE et al., 2009). The introduction of this crop in irrigated areas of Pernambuco and Bahia states in 1985 diversified the semi-arid region potential to meet both national consumption and exportation, allowing the production of highquality fruits over the year (FLORI and CASTRO, 2009). In 2011, a total of 342,528 tons of fruits were harvested in Brazil, being 112,779 and 107,755 tons respectively produced by São Paulo and Pernambuco, the largest Brazilian state producers (AGRIANUAL, 2014).

However, despite crop's rusticity, the nematode Meloidogyne enterolobii presence in the main producing regions has compromised agricultural production, leading the plants to death in some cases (CARNEIRO et al., 2001; TORRES et al., 2005). Since this nematode species first identification in Petrolina (Pernambuco), Curaçá (Bahia), by Carneiro et al. (2001), it has been found in other states of Brazil such as Rio Grande do Norte (TORRES et al., 2004), Ceará (TORRES et al., 2005), Rio de Janeiro (LIMA et al., 2005), São Paulo (ALMEIDA et al., 2006), Piauí (SILVA et al., 2006), Paraná (CARNEIRO et al., 2006), Paraíba (GOMES et al., 2007), Mato Grosso (SOARES et al., 2007), Mato Grosso do Sul (ASMUS et al., 2007), Espírito Santo (LIMA et al., 2007), Minas Gerais (OLIVEIRA et al., 2007; SILVA et al., 2008), Santa Catarina and Rio Grande do Sul (GOMES et al., 2008), Maranhão (SILVA et al., 2008), Goiás (CARNEIRO et al., 2008), Tocantins (CHARCHAR et al., 2009), and Alagoas (CASTRO and SIQUEIRA, 2010), severely harming commercial guava plantations.
The primary symptom of the disease is the presence of galls in the root system, which can be parasitized in both superficial radicles and the pivoting root more than $50 \mathrm{~cm}$ deep. Reflex symptoms are characterized by generalized yellowing of shoot, strong bronzing of leaves, total plant defoliation, drying of branches, and plant death (MARANHÃO et al., 2001, GOMES et al., 2011). Parasitized guava can live with the nematode for months, maintaining a production around $70 \%$ of that obtained in healthy plants (SOUZA et al., 2007).

Among the strategies of $M$. enterolobii management are the use of free-nematode areas, cultivation of healthy guava seedlings, use of desinfested machinery and agricultural implements, prohibition of machinery traffic on infested areas, and orchard periodic monitoring. If outbreaks of disease occur in the installed orchard, diseased plants should be eradicated by destroying them by fire and pits isolated from the irrigation system. Nematode control is difficult in the infested orchard because it is a perennial crop with permanent fruit production and the application of systemic nematicides is not recommended (MARANHÃO et al., 2001).

Genetic resistance is the main form for controlling this nematode. The identification of resistant genotypes is considered an effective, economically viable, and environmentally safe strategy. Studies aiming at identifying sources of resistance have been reported in the literature, as in Carneiro et al. (2007), who identified accessions of $P$. friedrichsthalianum Berg-Nied and P. cattleyanum as moderately resistant and immune, respectively. Likewise, Almeida et al. (2009) identified resistant accessions of araçá-boi (Eugenia stipitata) and other araçá species belonging to the genus Psidium. Lastly, Miranda et al. (2012) also identified accessions of $P$. cattleyanum resistant to $M$. enterolobii.

In order to make viable the use of genetic resistance, the compatibility of araçá rootstocks for 'Paluma' scions has been tested (CARNEIRO et al., 2007; ALMEIDA et al., 2009). Although it proved its feasibility, in some cases a lack of compatibility in araçá inarches has also been reported (ROBAINA et al., 2012). At the same time, studies that clarify the mechanisms involved in the response of Psidium species to nematodes are necessary for a longer duration and effectiveness of the adopted management strategies. This study aimed to assess the penetration, development, and reproduction of $M$. enterolobii and induced cellular responses in roots of four Psidium species from the Active Germplasm Bank of the Embrapa Semiarid to guava root-knot nematode, comparing them with the susceptible 
commercial cultivar 'Paluma'.

\section{MATERIAL AND METHODS}

Seeds of Psidium from the Active Bank of Guava and Araçá Germplasm of the Embrapa Semiarid were sown in a vermiculite-based substrate for vegetable production contained in pots of 15 $\times 17.5 \times 12.3 \mathrm{~cm}$ (height $\times$ hole-mouth diameter $\times$ bottom diameter), which were maintained in a greenhouse. Germination occurred between 30 and 40 days after sowing. One week after germination, plants were transplanted to 1.5 -L capacity pots containing autoclaved soil. The experiments were carried out with four-month-old plants.

The inoculum of M. enterolobii was obtained from a commercial plantation of guava located in Petrolina, PE, Brazil. Roots infected by nematodes were processed for egg extraction using the technique described by Hussey and Barker (1973). Hatching chambers were prepared in order to obtain the second stage juveniles $\left(\mathrm{J}_{2}\right)$. The first hatching occurred after 24 hours, but the juveniles used were those that hatched after 48 hours.

For inoculation, inoculum suspension was placed into holes around the plants with a pipette, at a distance of $1.5 \mathrm{~cm}$ from the stem, and 2.5 $\mathrm{cm}$ deep. Plants were maintained in a greenhouse at a temperature between 28 and $30{ }^{\circ} \mathrm{C}$ and a daily irrigation was performed according to crop requirements.

Three experiments were carried out. In experiments 1 and 2, penetration and development of $M$. enterolobii were assessed by varying density and type of inoculum (eggs or $\mathrm{J}_{2}$ ), maintaining the same assessment periods. In experiment 3 , nematode reproduction was assessed with an increase in assessment period and reduction in inoculum density.

In experiment 1,60 plants of the genus $P$ sidium (15 of $P$. cattleyanum, 15 of $P$. friedrichstalianum, 15 of $P$. guajava, and 15 of $P$. guineense) were used, being the first species immune, the second resistant, and the other two susceptible to guava root-knot nematode. Plants were inoculated with 6,000 eggs of $M$. enterolobii and assessed at 5, 10, and 20 days after inoculation (DAI).

In experiment 2, 44 plants of the genus Psidium (11 of P. cattleyanum, 11 of $P$. friedrichstalianum, 11 of P. guajava, and 11 of $P$. guineense) were used. Inoculation was performed with $8,000 \mathrm{~J}_{2}$ of $M$. enterolobii and plants were assessed at 5,10 , and 20 DAI.

In experiment 3, 12 plants of the genus
Psidium (4 of $P$. friedrichstalianum, 4 of $P$. guajava, and 4 of $P$. guineense) were used. At the time of this experiment, seedlings of $P$. cattleyanum were not available and, therefore, this species was not included. Plants were inoculated with $5,000 \mathrm{~J}_{2}$ of $M$. enterolobii and the reproduction factor $(\mathrm{RF}=$ final population/initial population) was determined at $60 \mathrm{DAI}$.

At 5, 10, and 20 DAI in experiments 1 and 2, and at $60 \mathrm{DAI}$ in experiment 3 , roots were separated from the shoot, being carefully washed in running water. Subsequently, these roots were packaged inside identified plastic bags, which were taken to the laboratory.

Nematode staining in plant tissue in experiments 1 and 2 was performed in the laboratory by using the acid fuchsin method (BYRD et al., 1983) in order to visualize the vermiform $\mathrm{J}_{2}$, "sausage" and oval forms ( $\mathrm{J}_{3}$, and $\mathrm{J}_{4}$ ), and females. Roots were submitted to staining using a dye solution composed of $75 \mathrm{~mL}$ distilled water, $25 \mathrm{~mL}$ glacial acetic acid, and $350 \mathrm{mg}$ acid fuchsin. All specimens were counted inside the roots in each treatment, being determined the proportional number of individuals at each development stage. In experiment $3, \mathrm{~J}_{2}$ was extracted from soil (JENKINS, 1964) and eggs from eggmasses in roots (COOLEN and D'HERDE, 1972). Quantifications were carried out in Peter's chamber under a stereoscopic microscope. Subsequently, the numbers of eggs per root and per gram of roots were determined. The reproduction factor was determined according to Oostenbrink (1966), dividing the final population (number of $\mathrm{J}_{2}$ in the soil + eggs per roots) by the initial one (number of inoculated $\mathrm{J}_{2}$ ).

For histological assessment in light microscopy of Psidium spp. roots, extra replications of all treatments of experiment 2 were added. Roots were separated from the shoot, washed in running water, and fixed in FAA 70 (JOHANSEN, 1940) for 72 hours and preserved in $70 \%$ ethyl alcohol (JENSEN, 1962). Subsequently, the material was dehydrated in ethyl series ( $70 \%$ to $100 \%$ ), immersed in butyl acetate, paraffin-embedded, and sectioned on a rotary microtome (MRPO9 LUPETEC) into cross sections, whose cuts ranged from 5 to $8 \mu \mathrm{m}$ thick. The obtained sections were submitted to double staining composed of Alcian Blue and Safranin $(1: 1, \mathrm{v} / \mathrm{v})$ and mounted on permanent slides with Canada balsam (BUKATSCH, 1972). The analysis and photographic record of the most relevant anatomical characters were performed in a Top Light B2 light microscope using the software BEL MicroImage Analyser, obtaining the corresponding scales. 


\section{RESULTS AND DISCUSSION}

In experiment 1 , the first infection in guava 'Paluma' was only possible to observe at $10 \mathrm{DAI}$, with the presence of vermiform juveniles. Events such as hatching were delayed, and "sausage" and globose forms were only observed at 20 DAI possibly due to egg inoculation (Figure 1).

In experiment 2 , the first infection observation in guava 'Paluma' with the presence of vermiform juveniles occurred at 5 DAI. Consequently, only globose forms were observed at $20 \mathrm{DAI}$, including the presence of eggs, which were observed only in 'Paluma' (Figure 2).

Vermiform juveniles were observed in roots of $P$. guineense at 5 DAI (Figures 1 and 2). These forms evolved to globose and adult females in experiment 2 (Figure 2), in which plants were inoculated with $\mathrm{J}_{2}$. However, this behavior was not observed in experiment 1 (Figure 1), in which plants were inoculated with eggs. Despite this, nematode development in $P$. guineense was slower than in $P$. guajava since several vermiform juveniles and some "sausage" forms could still be found in P. guineense at $20 \mathrm{DAI}$.

No penetration of $\mathrm{J}_{2}$ occurred in plants of $P$. cattleyanum at 5 DAI, but "sausage" forms were observed at 10 and 20 DAI. Although M. enterolobii has penetrated in $P$. friedrichstalianum, no changes were observed in development forms from 5 to 10 DAI. Vermiform juveniles remained until 20 DAI with some evolution to "sausage" forms.

In experiment 3 , no significant differences were found between species. Only P. guajava 'Paluma' was susceptible to $M$. enterolobii by reproduction factor (Table 1). The absence of eggs in some of the plants of $P$. friedrichstalianum and $P$. guineense may have contributed to the high coefficients of variation (CV) found. Consequently, these high $\mathrm{CV}$ values did not allow detecting significant differences between resistant and susceptible genotypes in egg production although the number of $\mathrm{J}_{2}$ in the soil of $P$. friedrichstalianum and $P$. guineense was significantly lower when compared to the values found in P. guajava. Moreover, the period of 60 DAI may not have been sufficient for the nematode to express all its reproductive potential, especially in $P$. guajava.

Guava 'Paluma' is known to be susceptible

to $M$. enterolobii. In this sense, several authors have observed this nematode parasitizing guava (MARANHÃO et al., 2001; CARNEIRO et al. ,2007; ALMEIDA et al., 2009; CASTRO et al., 2012). Despite this susceptibility, P. cattleyanum,
P. friedrichstalianum, and $P$. guineense presented resistance to guava root-knot nematode, characterized mainly by a developmental delay and life cycle extension, corroborating other studies that registered different levels of resistance in other species of Psidium, such as Carneiro et al. (2007) and Castro et al. (2008).

Histological sections showed signs of deterioration in giant cells of plants susceptible at 20 DAI (Figure 3A). The nematode did not complete the cycle in resistant species since juveniles did not reach the adult stage and hence did not reproduce (RF $=0$ ). Apparently, modifications in cells of resistant species were incipient (Figures 3B, 3C, and 3D), suggesting that induced feeding cells did not provide the required supply for the proper development of juveniles. Freitas et al. (2012) observed adult females in guava 'Paluma' roots alongside fully formed giant cells from 27 to 31 DAI whereas the presence of $J_{2}$, $\mathrm{J}_{3}$, and $\mathrm{J}_{4}$ was observed in $P$. cattleyanum, but without evolution to the adult stage.

The interaction of root-knot nematode and host plant is dynamic and complex. To complete the life cycle, after egg hatching, $\mathrm{J}_{2}$ must penetrate the root of a susceptible plant and initiate a structural, physiological, and molecular reorganization of the host, resulting in the formation of well-formed feeding points known as giant cells (WILLIAMSON and KUMAR, 2006; FULLER et al., 2008). Changes in giant cells are correlated with changes in parasites (FREITAS et al., 2012) and it should have affected $\mathrm{J}_{2}$ development in this study, being slower in $P$. cattleyanum, P. friedrichstalianum, and P. guineense.

The delay in $\mathrm{J}_{2}$ development increases cycle duration and may affect nematode reproduction, but it does not ensure that population density and hence the resulting damage increase over time. The knowledge of how resistance affects nematode life cycle has a decisive impact on the adopted management and, consequently, on the effective duration of resistance in the field.

Another important aspect for management efficiency is associated with the viability of using a resistant genotype as a rootstock. Almeida et al. (2009) found sources of resistance to M. enterolobii among accessions of $P$. cattleyanum. However, these accessions were not compatible for grafting with guava 'Paluma', which made it unfeasible the use of these materials as rootstock for this cultivar. On the other hand, Freitas et al. (2012) observed a good development of guavas grafted on $P$. friedrichstalianum, with plants being more vigorous than those grafted on $P$. cattleyanum. From the ten plants grafted on $P$. friedrichstalianum 
that were taken to the field, six remained alive and produced buds, flowers, and fruits. However, an incompatibility reaction occurred in plants grafted on P. cattleyanum.

Resistance in P. guajava to M. enterolobii has not yet been reported, which makes it difficult to develop breeding programs (MARTINS et al., 2013). On the other hand, the genetic variability of guava and araçá due to the typical allogamy of these species is another reason to collect and test new genotypes, increasing the possibilities of finding new sources of resistance and compatibility of grafting.

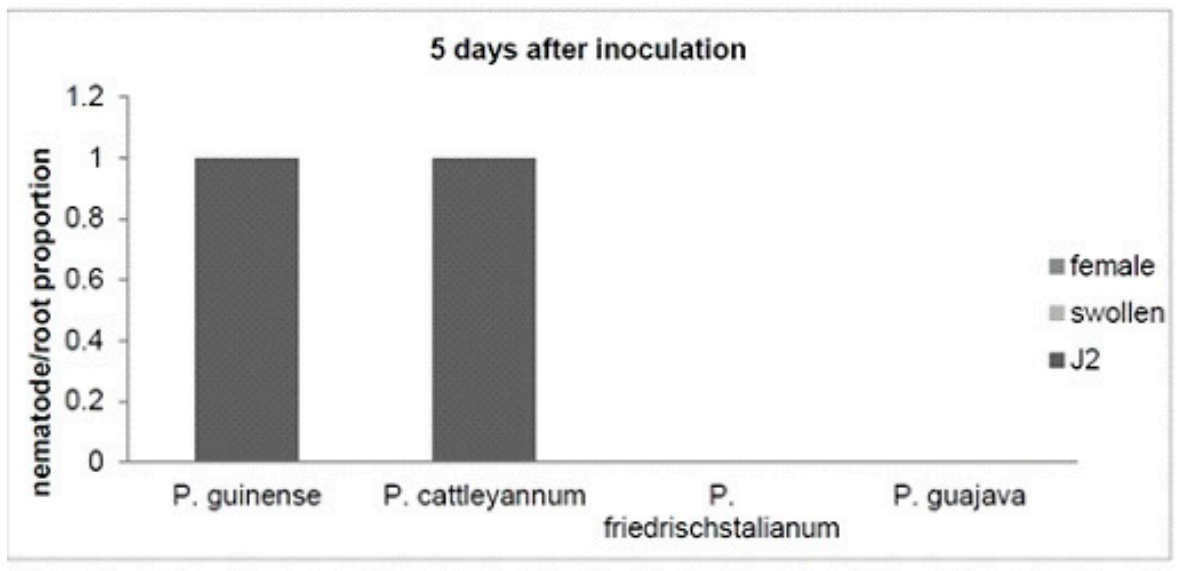

\section{0 days after inoculation}

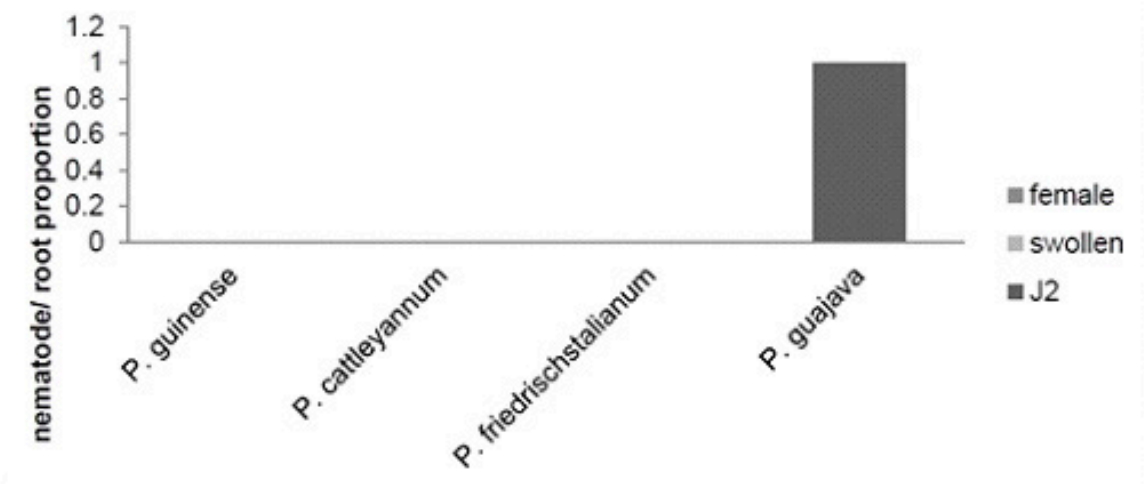

20 days after inoculation

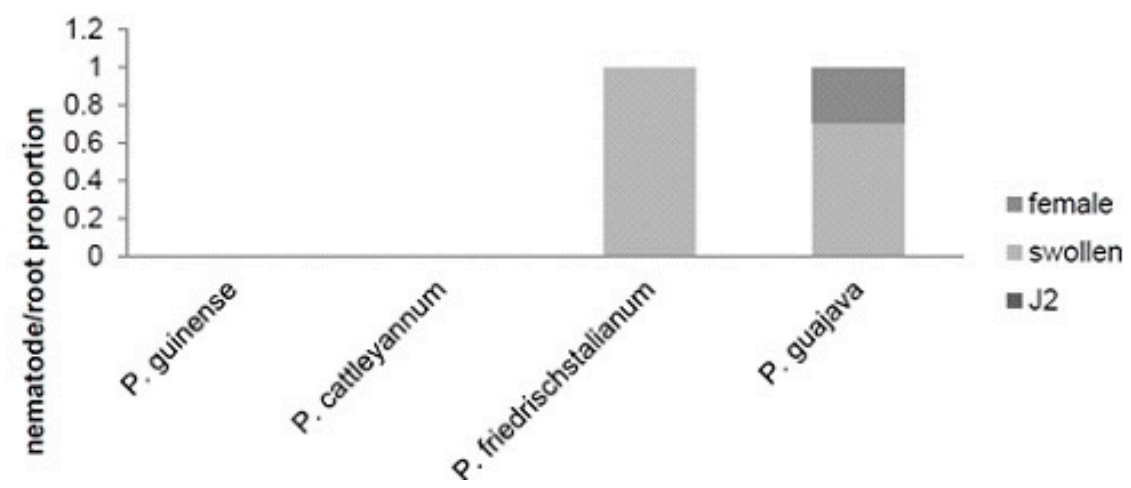

FIGURE 1 Penetration and development of Meloidogyne enterolobii in roots of Psidium guajava cv. 'Paluma', P. guineense, $P$. cattleyanum, and $P$. friedrichstalianum at 5, 10, and 20 days after inoculation of 6,000 eggs per plant. 

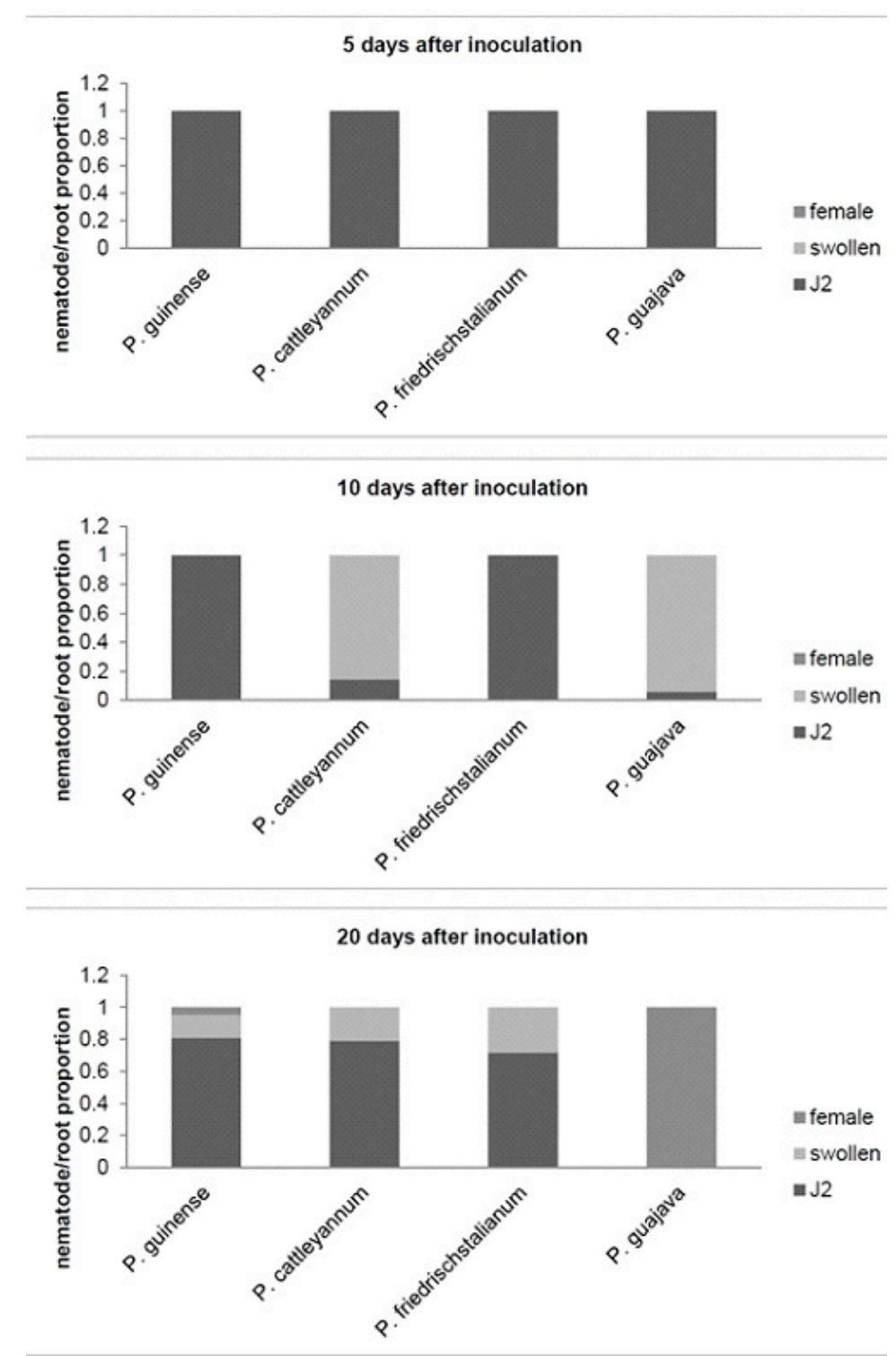

FIGURE 2- Penetration and development of Meloidogyne enterolobii in roots of Psidium guajava cv. 'Paluma', $P$. guineense, $P$. cattleyanum, and $P$. friedrichstalianum at 5, 10, and 20 days after inoculation of 8,000 second stage juveniles $\left(\mathrm{J}_{2}\right)$ per plant. 


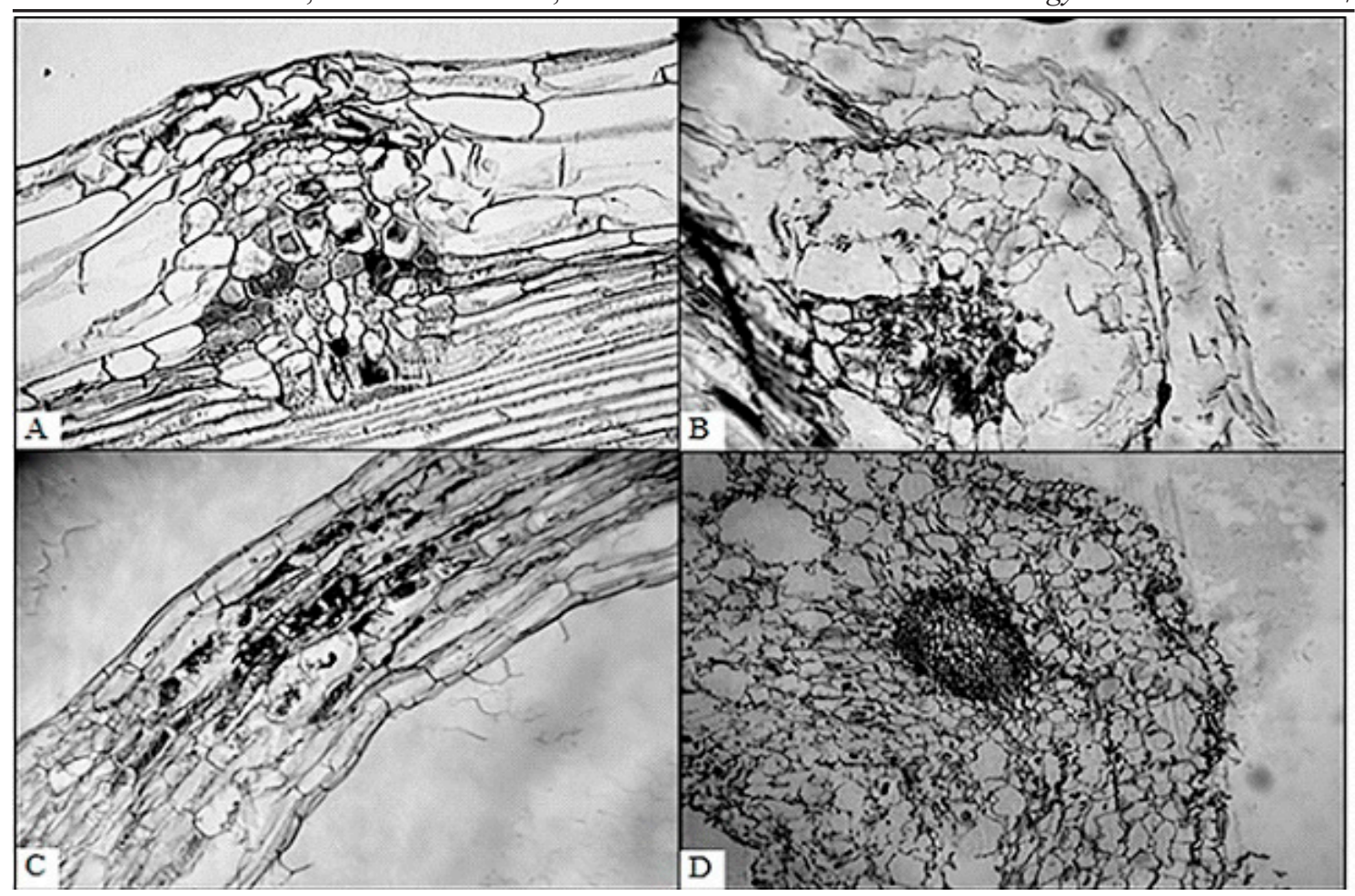

FIGURE 3 - Comparisons among histological sections of Psidium species. P. guajava (A); P. cattleyanum (B); P. guineense (C); and P. friedrichstalianum (D).

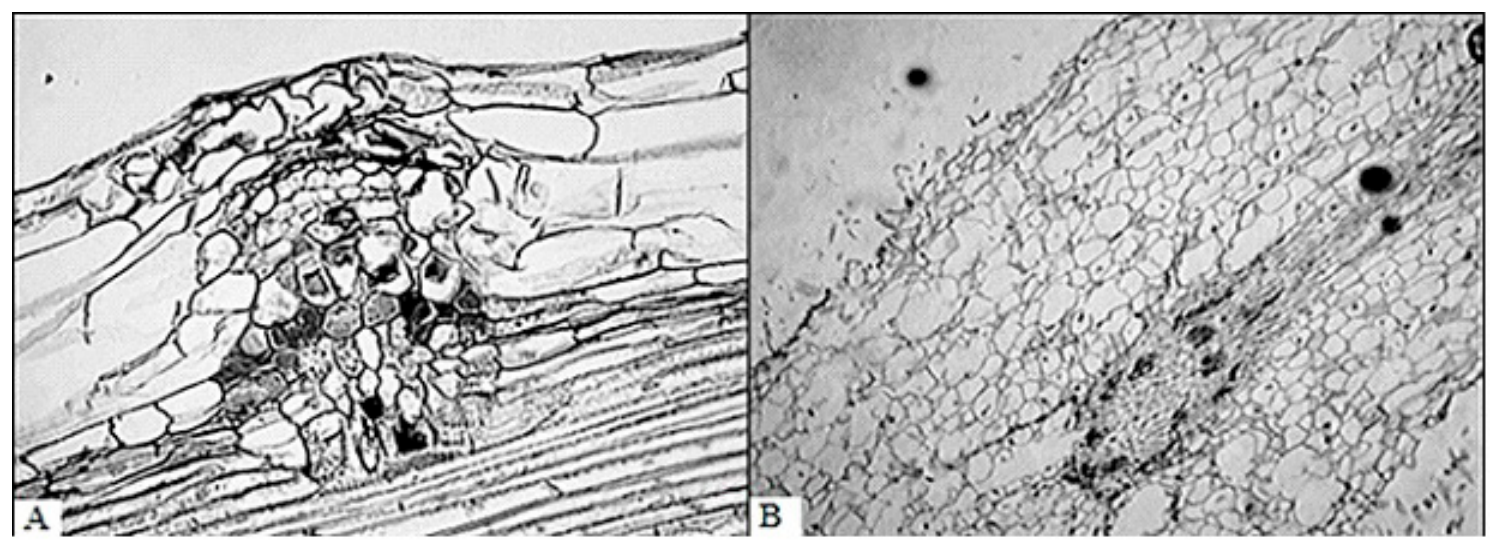

FIGURE 4- Comparisons between histological sections of infected (A) and health (B) Psidium guajava. 
TABLE 1- Reproduction of Meloidogyne enterolobii in Psidium guajava 'Paluma', P. guineense, P. cattleyanum, and $P$. friedrichstalianum roots at 60 days after inoculation of 5,000 second stage juveniles $\left(\mathrm{J}_{2}\right)$ per plant.

\begin{tabular}{lcccc}
\hline Psidium species & $\mathrm{J}_{2}$ in scil & Egg s'root & Eggs $/$ g of root & RF \\
\hline P.guineense & $200 \mathrm{~b}$ & $4540 \mathrm{a}$ & $2120 \mathrm{a}$ & 0,90 (R) \\
$P$. friedrichstaiionzim & $40 \mathrm{~b}$ & $955 \mathrm{a}$ & $299 \mathrm{a}$ & 0,19 (R) \\
P. guajova & $960 \mathrm{a}$ & $7070 \mathrm{a}$ & $3539 \mathrm{a}$ & 1,40 (S) \\
CV (\%) & 54,94 & 65,28 & 60,17 & \\
\hline
\end{tabular}

Data are means of four replicates and were transformed to $\sqrt{ }(x+0.5)$ prior to statistical analysis. Means within columns followed by different letters indicate significant difference based on Tukey test $(\mathrm{P}<0.05)$. RF reproductive factor. CV coefficient of variation.

\section{CONCLUSIONS}

Rootstocks of P. cattleyanum, P. friedrichstalianum, and $P$. guineense showed resistance to guava root-knot nematode. The susceptibility of guava 'Paluma' to $M$. enterolobii was confirmed.

In contrast to $P$. guajava, the other species present undeveloped feeding sites at 20 DAI.

Morphological changes found in species that presented resistance ( $P$. cattleyanum, $P$. friedrichstalianum, and $P$. guineense) were incipient because the nematode did not reach the adult stage and hence was unable to complete its life cycle.

Genetic resistance to $M$. enterolobii appears to be initially in P. cattleyanum. However, the assessment of other species of araçá is necessary, including other accessions of $P$. guineense, a species botanically similar to $P$. guajava, thus facilitating the compatibility in grafts with commercial guavas.

\section{REFERENCES}

AGRIANUAL: 'Anuário da Agricultura Brasileira'. São Paulo: FNP Consultoria \& Comércio, 2014. p.297-300

ALMEIDA, A.M.; GOMES, V.M.; SOUZA, R.M; CORREA, F.M. Efeito de diferentes fontes de matéria orgânica incorporadas ao solo sobre Meloidogyne mayaguensis, em casa de vegetação. Nematologia Brasileira, Piracicaba, v. 3, n.1, p.406, 2009.
ALMEIDA, E.J.; SOARES, P.L.M.; SANTOS, J.M.; MARTINS, A.B.G. Ocorrência de Meloidogyne mayaguensis na cultura da goiaba (Psidium guajava) no Estado de São Paulo. Nematologia Brasileira, Campinas, v.30, n.2, p.112-3, 2006.

ASMUS, G.L.; VICENTINI, E.M.; CARNEIRO, R.M.D.G. Ocorrência de Meloidogyne mayaguensis em goiabeira no Estado de Mato Grosso do Sul. Nematologia Brasileira, Campinas, v.30, n.3, p.112, 2007.

BEZERRA, J.E.F.; LEDERMAN, I.E.; SILVA JUNIOR, J.F.; PROENÇA, C.E.B. Araçá. In: VIEIRA, R.F.; COSTA, R.S.A.; SILVA, D.B.; FERREIRA, F.R.; SANO, S.M. Frutas nativas da região Centro-Oeste. Brasília: Embrapa Recursos Genéticos e Biotecnologia, 2006. p. 42-63.

BUKATSCH, F. Bemerkungen zur doppelfarbung astrablau-safrain. Mikrokosmos, Stuttgart, v.61, n. 8, p. $255,1972$.

BYRD, D.W.; KIRKPATRICK, J.; BARKER, K.R. An improved technique for clearing and staining plant tissues for detection of nematodes. Journal of Nematology, Lawrence, v.15, n.1, p.142-3, 1983.

CARNEIRO, R.G.; MONACO, A.P.A.; MORITZ, M.P.; NAKAMURA, K.C.; SCHERER, A. Identificação de Meloidogyne mayaguensis em goiabeira e em plantas invasoras, em solo argiloso, no Estado do Paraná. Nematologia Brasileira, Campinas, v.30, n.3, p.293-8, 2006.

CARNEIRO, R.M.D.G.; CIROTTO, P.A.; SILVA, D.B.; CARNEIRO, R.G. Resistance to Meloidogyne mayaguensis in Psidium spp. accessions and their grafting compatibility with $P$. guajava cv. Paluma. Fitopatologia Brasileira, Brasília, DF, v.32, n.6, p.281-4, 2007. 
CARNEIRO, R.M.D.G.; MOREIRA, W.A.; ALMEIDA, M.R.A.; GOMES, A.C.M.M. Primeiro registro de Meloidogyne mayaguensis em goiabeira no Brasil. Nematologia Brasileira, Jaboticabal, v.25, n.2, p.223-8, 2001.

CARNEIRO, R.M.D.G.; SIQUEIRA, K.M.S.; SANTOS, M.F.A.; ALMEIDA, M.R.A.; TIGANO, M.S. Ocorrência de Meloidogyne mayaguensis em goiabeira e mamoeiro no Estado de Goiás. Fitopatologia Brasileira, Brasília, DF, v.33, p.S258, 2008. Suplemento

CASTRO, J. M. C.; FLORI, J. E.; SANTOS, C. A. F.; ANTUNES, E. F. Evalution of tolerance of Psidium species to the Meloidogyne mayaguensis nematode. In: INTERNATIONAL SYMPOSIUM ON GUAVA AND OTHER MYRTACEAE, 2., 2008, Merida. Abstract... Merida: CICY; INIFAP, 2008. p. 25.

CASTRO, J.M.C.; SANTOS, C.A.F.; FLORI, J.E.; SIQUEIRA, S.V.C.; NOVAES, P.A.R.; LIMA, R.G. Reaction of Psidium accessions to the Meloidogyne enterolobii root-knot nematode. Acta Horticulturae, The Hague, n.959, p.51-57, 2012.

CASTRO, J.M.C.; SIQUEIRA, T.A.S. Primeiro registro de Meloidogyne enterolobii em goiabeira no Estado de Alagoas. Nematologia Brasileira, Piracicaba, v.34, n.3, p.169-71, 2010.

CHARCHAR, J.M.; FONSECA, M.E.N.; BOITEUX, L.S.; LIMA NETO, A.F. Ocorrência de Meloidogyne mayaguensis em goiabeira no Estado de Tocantins. Nematologia Brasileira, Piracicaba, v.33, n.2, p.182-186, 2009.

COOLEN, W. A.; D'HERDE, C. J. A method for the quantitative extraction of nematodes from plant tissue. Merelbeke: State Nematology and Entomology Research Station, 1972. p.77.

FLORI, J.E.; CASTRO, J.M.C.A cultura da goiabeira irrigada no nordeste brasileiro. In: NATALE, W.; ROZANE, D.E.; SOUZA, H.A; AMORIM, D.A. (Ed.). Cultura da goiabeira do plantio a comercialização. Jaboticabal: FCAV/UNESP, 2009. v.2, p.507-24.

FREITAS, V.M.; CORREA, V.R.; MOTTA, F.C.; SOUSA, M.G.; GOMES, A.C.M.M.; CARNEIRO, M.D.G.; SILVA, D.B.; MATTOS, J.K.; NICOLE, M.; CARNEIRO, R.M.D.G. Resistant accessions of wild Psidium spp. to Meloidogyne enterolobii and histological characterization of resistance. Plant Pathology, Oxford, v.63, p.738-746, 2012.
FULlER, V.L.; LILLEY, C.J.; URWIN, P.E. Nematode resistance. New Phytologist, Cambridge, v.180, p.27-44, 2008.

GOMES, A.R.; FAUSTINO, J.F.; WILCKEN, S.R.S.; CARNEIRO, R.M.D.G.; AMBRÓSIO, M.M.Q.; SOUZA, N.L. Ocorrência de Meloidogyne mayaguensis em Psidium guajava L. no Estado da Paraíba. Fitopatologia Brasileira, Brasília, DF, v.32, p.273, 2007.

GOMES, C.B.; COUTO, M.E.; CARNEIRO, R.M.D.G. Registro de ocorrência de Meloidogyne mayaguensis em goiabeira (Psidium guajava L.) e fumo (Nicotiana tabacum L.) no Sul do Brasil. Nematologia Brasileira, Piracicaba, v.32, n.3, p.244-7, 2008.

GOMES, S.M.; SOMAVILLA, N.S.D.N.; BEZERRA, K.M.G.; MIRANDA, S. do C.; CARVALHO, P.S.; RIBEIRO, D.G. Anatomia foliar de espécies de Myrtaceae: contribuições à taxonomia e filogenia. Acta Botânica Brasileira, São Paulo, v.23, n.1, p.223-238, 2009.

GOMES, V.M.; SOUZA, R.M.; MUSSI-DIAS, V.; SILVEIRA, S.F.; DOLINSKI, C. Guava decline: a complex disease involving Meloidoyne enterolobii and Fusarium solani. Journal of Phytopathology, Berlin, v.159, n.1, p.45-50, 2011.

HUSSEY, R.S.; BARKER, K.R. A comparison of methods of collecting inocula of Meloidogyne spp., including new technique. Plant Disease Report, St Paul, v.57, n.12, p.1025-8, 1973.

JENKINS, W.R. A rapid centrifugal-flotation technique for separating nematodes from soil. Plant Disease Report, Saint Paul, v.48, n.4, p.692, 1964.

JENSEN, W. A. Botanical histochemistry, principles and practice. San Francisco: W. H. Freeman, 1962. p.408.

JOHANSEN, D. Plant microtechnique. New York: McGraw-Hill , 1940. p.523.

LIMA, I.M.; MARTINS, M.V.V.; SERRANO, L.A.L.; CARNEIRO, R.M.D.G. Ocorrência de Meloidogyne mayaguensis em goiabeira cv. Paluma, no Estado do Espírito Santo. Nematologia Brasileira, Piracicaba, v.31, n.2, p.132, 2007. 
LIMA, I.M.; SOUZA, R.M.; SILVA, C.P.; CARNEIRO, R.M.D.G. Meloidogyne spp. from preserved areas of Atlantic Forest in the State of Rio de Janeiro, Brazil. Nematologia Brasileira, Piracicaba, v.29, n.1, p.31-38, 2005.

MANICA, I. Frutas nativas, silvestres e exóticas 1: técnicas de produção e mercado: abiu, amora-preta, araçá, bacuri, biriba, carambola, cereja-do-riogrande, jabuticaba. Porto Alegre: Cinco Continentes, 2000. 327 p.

MARANHÃO，S.R.V.L.; MOURA，R.M.; PEDROSA, E.M.R. Reação de indivíduos segregantes de goiabeira a Meloidogyne incognita 1 e $M$. mayaguensis. Nematologia Brasileira, Piracicaba, v.25, p.191-195, 2001.

MARTINS, L.S.S.; MUSSER, R.S.; SOUZA, A.G.; RESENDE, L.V.; MALUF, W.R. Parasitismo de Meloidogyne enterolobii em espécies de Myrtaceae. Revista Brasileira de Fruticultura, Jaboticabal, v.35, n.2, p.477-84, 2013.

MIRANDA, G.B; SOUZA, R.M.; GOMES, V.M.; FERREIRA, T.F.; ALMEIDA, A.M. Avaliação de acessos dePsidium spp. quanto à resistência a Meloidogyne enterolobii. Bragantia, Campinas, v. 71, p.52-8, 2012.

OLIVEIRA, R.D.L.; SILVA, M.B.; AGUIAR, N.D.C.; BÉRGAMO, F.L.K.; COSTA, A.S.V.; PREZOTTI, L. Nematofauna associada à cultura do quiabo na região leste de Minas Gerais. Horticultura Brasileira, Brasília, DF, v.25, n.1, p.88-93, 2007.

OOSTENBRINK, M. Major characteristics of the relation between nematodes and plants. Mededelingen Van De landbouwhogeschool Te Wageningen, Wageningen, v.66, n.4, p.1-46, 1966.

PEREIRA, F.M.; NACHTIGAL, J.C. Goiabeira. In: BRUCKNER, C.H. (Ed.). Melhoramento de fruteiras tropicais. Viçosa: UFV, 2003. p.267-89.

ROBAINA, R.R.; MARINHO, C.C.; SOUZA, R.M.; CAMPOS, G.S. Subenxertia da goiabeira 'Paluma' com araçazeiros resistentes a Meloidogyne enterolobii (sin. M. mayaguensis). Revista Brasileira de Fruticultura, Jaboticabal, v.34, n.3, p.951-5, 2012.
ROZANE, D.E.; BRUGNARA, V.; SOUZA, H.A.; AMORIM, D.A. Condução arquitetura e poda da goiabeira para 'mesa' e/ou 'indústria'.In: NATALE, W.; ROZANE, D.E.; SOUZA, H.A; AMORIM, D.A. (Ed.). Cultura da goiabeira do plantio a comercialização. Jaboticabal: FCAV, UNESP, 2009. v. 2 , p. 507-24

SILVA, G.S.; PEREIRA, A.L.; ARAÚJO, J.R.G.; CARNEIRO, R.M.D.G. Ocorrência de Meloidogyne mayaguensis em Psidium guajava no Estado do Maranhão. Nematologia Brasileira, Piracicaba, v.32, n.3, p.242-243, 2008.

SILVA, G.S.; SOBRINHO, A. C.; PEREIRA, A.L.; SANTOS, J.M. Ocorrência de Meloidogyne mayaguensis em goiabeira, no Estado do Piauí. Nematologia Brasileira, Piracicaba, v.30, n.3, p.307-9, 2006

SOARES, P.L.M.; ALMEIDA, E.J.; SILVA, A.R.; BARBOSA, B.F.F.; SANTOS, J.M. Novos registros de Meloidogyne mayaguensis no Brasil. Nematologia Brasileira, Piracicaba, v.31, n.2, p.145, 2007.

SOUZA, R.M.; NOGUEIRA, M.S.; LIMA, I.M.; MELARATO, M.; DOLINSKI C. Manejo dos nematoides das galhas da goiabeira em São João da Barra (RJ) e relato de novos hospedeiros. Nematologia Brasileira, Brasília, DF, v.30, p.1659, 2007.

TORRES, G.R.C.; COVELLO, V.N.; SALES JUNIOR, R.; PEDROSA, E.M.R.; MOURA, R. Meloidogyne mayaguensis em Psidium guajava no Rio Grande do Norte. Fitopatologia Brasileira, Brasília, DF, v.29, n.5, p.570, 2004.

TORRES, G.R.C.; SALES JUNIOR, R.; NERIVANIA, V.; REHN, C.; PEDROSA, E.M.R.; MOURA, R.M. Ocorrência de Meloidogyne mayaguensis em goiabeira no Estado do Ceará. Nematologia Brasileira, Campinas, v.29, n.1, p.105-7, 2005.

WILLIAMSON, V.M.; KUMAR, A. Nematode resistance in plants: the battle underground. Trends in Genetics, Cambridge, v.22, p.396-403, 2006. 